Terr. Atmos. Ocean. Sci., Vol. 17, No. 4, 723-737, December 2006

\title{
Types of Gas Hydrates in Marine Environments and Their Thermodynamic Characteristics
}

\author{
Duo-Fu Chen ${ }^{1,2, *}$, Zheng Su ${ }^{1}$, and Lawrence M. Cathles ${ }^{3}$
}

(Manuscript received 31 October 2005, in final form 31 March 2006)

\begin{abstract}
The hydrates in marine environment can be grouped into two categories, diffusion gas hydrates and vent gas hydrates. The diffusion gas hydrates occur widely in an area where bottom simulation reflector (BSR) was recorded in seismic profiles, and is a thermodynamic equilibrium system of hydrates and water with dissolved methane within gas hydrate stability zone (GHSZ). The hydrates are buried in a distance apart from the seafloor and are characterized by low concentrations. The vent gas hydrates occur in an area where gas vents out of the seafloor. It is a thermodynamic disequilibrium system of hydrate, water and free gas, occurs in a zone that extends from the base of GHSZ to the seafloor, and is characterized by high concentration. Reported evidences show that these two types of hydrates are possibly occurring in the South China Sea.
\end{abstract}

(Key words: Classification, Gas hydrate, Thermodynamics, Methane solubility, Hydrate ridge, South China Sea)

\section{INTRODUCTION}

Gas hydrate is an ice-like crystalline mineral distributed on continental slopes worldwide where temperature and pressure are suitable for hydrate stability (Sloan 1998; Kvenvolden and Lorenson 2001). In the last decade, tremendous data have been accumulated from geophysical surveys, the Ocean Drilling Program (ODP), direct seafloor observation and samplings devoted to gas hydrate. Enormous progresses have been made toward a better under-

\footnotetext{
${ }^{1}$ Key Laboratory of Marginal Sea Geology, Chinese Academy of Sciences, Guangzhou, China

2 Gas Hydrate Research Center, Chinese Academy of Sciences, Guangzhou, China

3 Department of Earth \& Atmospheric Sciences, Cornell University, New York, USA

* Corresponding author address: Dr. Duo-Fu Chen, Key Laboratory of Marginal Sea Geology, Chinese Academy of Sciences, Guangzhou, China; E-mail: cdf@gig.ac.cn
} 
standing of hydrate occurrence and formation in marine sediments (e.g., Paull et al. 2000; Trehu et al. 2003).

The evidence for the occurrence of gas hydrate as bottom simulation reflector (BSR) in seismic profiles (e.g., Hyndman and Davis 1992) was identified in a great number of marine sites worldwide (Sloan 1998; Kvenvolden and Lorenson 2001). ODP in areas where BSR typically occur yields results demonstrating that gas hydrate accumulates in the subsurface in a distance apart from the seafloor and that no free gas occurs within the GHSZ (Paull et al. 2000; Trehu et al. 2003, 2004). At the same time, seafloor observation and sampling and ODP drilling found that gas hydrate outcrops on the seafloor where gas actively vents into the overlying ocean to form a gas plume in a seawater column (Suess et al. 1999; Sassen et al. 2001; MacDonald et al. 2002, 2003; Heeschen 2003; Leifer and MacDonald 2003), and free gas exists within the GHSZ (Milkov et al. 2004).

ODP 204 drilled at the southern summit of Hydrate Ridge (Trehu et al. 2003) shows the difference in hydrate occurrence (Fig. 1). Very high concentrations of gas hydrates are present in about 30 - $40 \%$ of the pore space that extends from the seafloor to $\sim 30 \mathrm{mbsf}$ (zone C) where gas venting is known on the seafloor, while no gas hydrate is present in the upper $\sim 45 \mathrm{mbsf}$ away from this southern summit. Between $\sim 45 \mathrm{mbsf}$ and the base of the GHSZ (zone B), gas hydrate occupies only $2-4 \%$ of the pore space (Trehu et al. 2004). ODP 164 at the Blake Ridge yields similar characteristics of hydrate occurrence. Hydrate occupies on average 4- $6 \%$ of the porosity in sediments at 186 - 451 mbsf in Sites 994, 995 and 997 where the BSR occurs (Paull et al. 2000). However, hydrate was recovered from all five boreholes at Site 996 at depths ranging from just below the seafloor to $\sim 60$ mbsf over the Blake Ridge Diapir where gas actively vents (Paull et al. 2000), and the hydrate concentrations are estimated to be about $10 \%$ of the pore space on average (Paull et al. 2000).

As a result, remarkably distinct characteristics of hydrate occurrence and different thermodynamics of gas hydrate system have been observed in continental slopes in the world. However, no literature is available in regard to systematic classification of gas hydrates in such a marine environment based on the thermodynamics and distribution of gas hydrates that occur in the areas where BSR occurs (named diffusion gas hydrate) and or in the gas vent sites (named vent gas hydrate). Here, we will address the characteristics of occurrence and thermodynamics of diffusion gas hydrates and vent gas hydrates, and then use the methane equilibrium solubility of these two types of hydrates to constrain their possible occurrences. Finally, we will discuss the possible occurrences of these two types of hydrates in the northern South China Sea.

\section{GAS HYDRATE END MEMBERS IN CONTINENTAL SLOPE}

\subsection{Two-Phase Hydrate: Diffusion Gas Hydrate}

Diffusion gas hydrate is defined as gas hydrate that occurs in an area where BSR was identified in seismic record profile. Within the GHSZ, there are hydrate and water with dissolved methane rather than free gas. Dissolved methane in pore water migrates by the diffusion process. Therefore, this type of gas hydrate was named as Diffusion Gas Hydrate. 


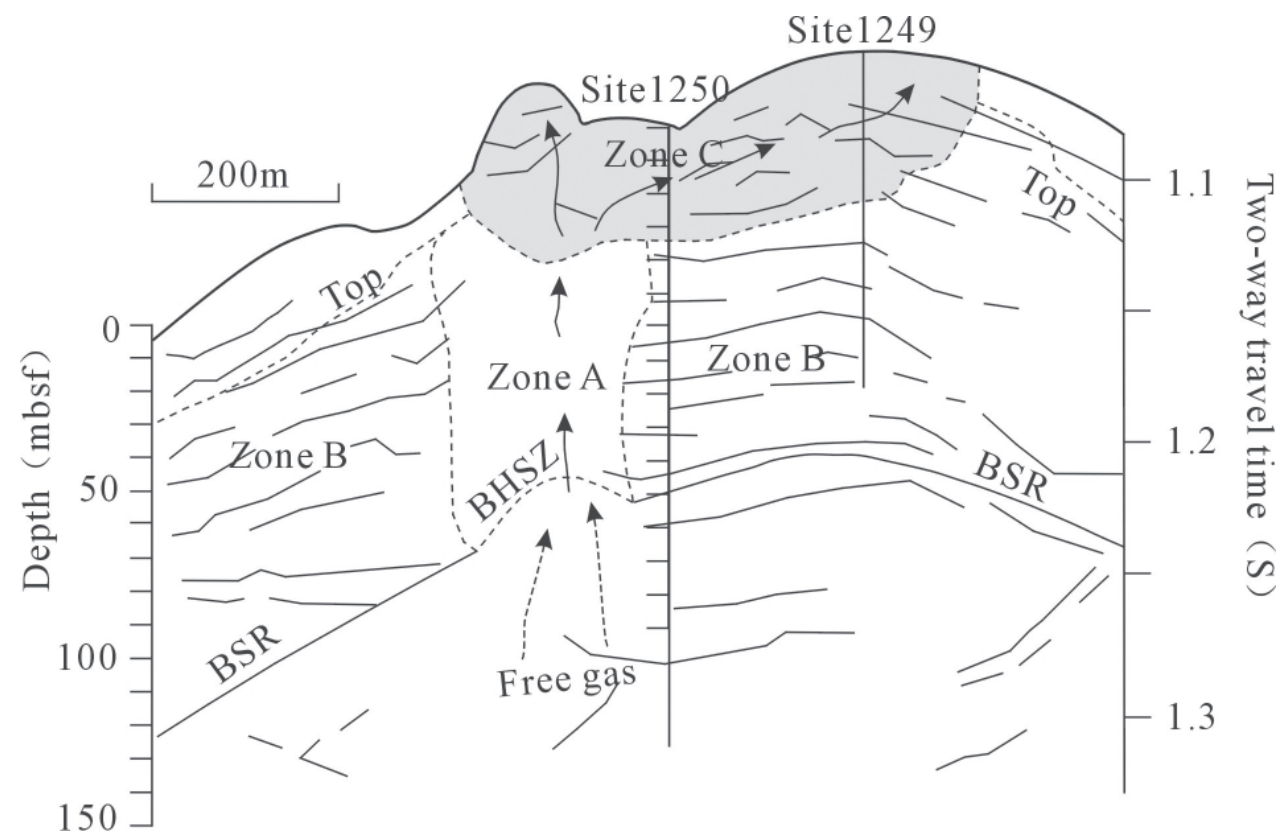

Fig. 1. Schematic illustration of gas hydrate occurrence across the southern summit of Hydrate Ridge (after Trehu et al. 2004). BHSZ is the base of the hydrate stability zone. Zone $\mathrm{C}$ and possibly zone $\mathrm{A}$ are a three-phase hydrate system, while zone B is a two-phase hydrate system. Arrows show the route of gas venting. Vent gas from a free gas zone under BSR may migrate to zone $\mathrm{C}$ through zone $\mathrm{A}$ where is a wipeout zone in seismic profile.

Most of the ocean floor is within the appropriate regime of pressure and temperature for gas hydrate to be stable (Fig. 2a), but an adequate gas source for hydrate accumulation is normally restricted to some regions on continental slopes. Biogenic methane either from in situ conversion of organic carbon within the GHSZ or from free gas zone beneath the GHSZ is the major source of gas (Zatsepina and Buffett 1997; Xu and Ruppel 1999). Dissolved methane may precipitate as hydrate in the subsurface when methane concentration in pore water exceeds the equilibrium solubility of methane in water and hydrate system (Fig. 2b) (Buffett and Zatsepina 2000; Davie and Buffett 2003). However, if dissolved methane is not significant in amount, free gas will not be formed within the GHSZ suggesting that this type of gas hydrate is a two-phase system of hydrate and water. 
(a)

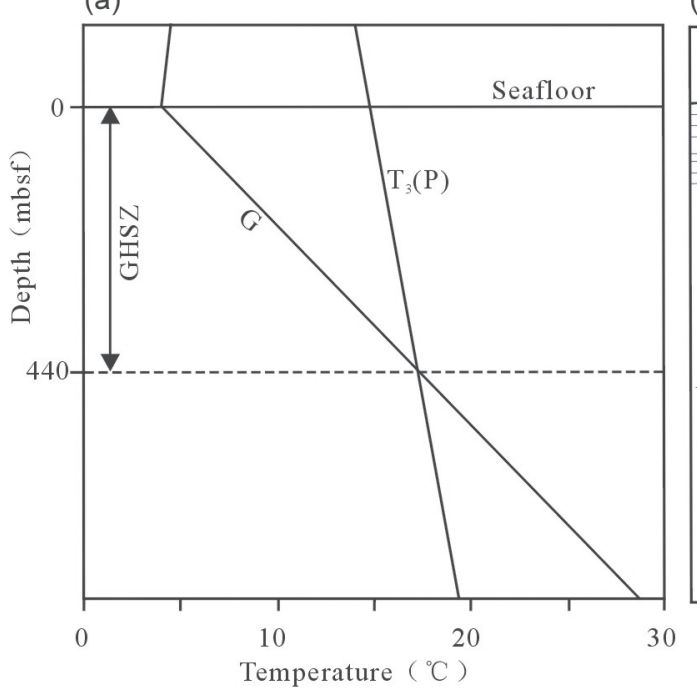

(b)

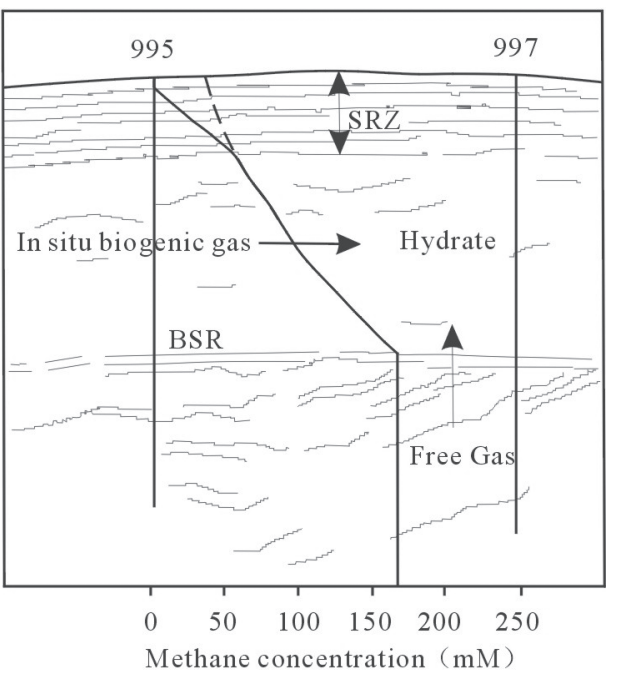

Fig. 2. Schematic profile of diffusion gas hydrate at Blake Ridge. (a) Shows the range of temperature and pressure that constrain the gas hydrate stability zone (GHSZ). GHSZ extending from 440 mbsf to the seafloor shows that hydrate could be accumulated within the GHSZ. G is the thermal gradient, and $\mathrm{T}_{3}(\mathrm{P})$ is the stability curve of methane hydrate as calculated by using the program CSMHYD (Sloan 1998). (b) Shows the content of dissolved methane in pore water (solid line) and the equilibrium solubility of methane (dashed line) in a hydrate-water system across Blake Ridge (after Davie and Buffett 2003). The concentration of dissolved methane in pore water must exceed the equilibrium solubility of methane in hydrate-water system in order for hydrate to be accumulated. Hydrate accumulates at a distance apart from the seafloor within the GHSZ since the dissolved methane will vanish within the sulfate reducing zone (SRZ) through a microbiological process.

ODP 164 drilled at Black Ridge and ODP 204 at Hydrate Ridge where BSR occurs shows that gas hydrate do not occur right on the seafloor but is buried at a distance apart from the seafloor (Paull et al. 2000; Trehu et al. 2003). This is because anaerobic methane oxidation $\left(\mathrm{CH}_{4}+\mathrm{SO}_{4}^{2-} \rightarrow \mathrm{HS}^{-}+\mathrm{HCO}_{3}^{-}+\mathrm{H}_{2} \mathrm{O}\right)$ in sulfate reduction zone consumes methane in the uppermost sediments (Valentine and Reeburgh 2000). The decrease in sulfate concentration with depth is approximately linear until the sulfate concentration vanishes completely, and the concentration of dissolved methane also decreases to almost zero in this microbiological process. 
Therefore, the concentration of methane in the sediment pore water of sulfate reduction zone is lower than the methane equilibrium solubility in water and hydrate system, and no hydrate will be accumulated in the uppermost sediments (Fig. 2) (Davie and Buffett 2003).

Below the sulfate reduction zone and due to microbiological conversion of available organic carbon to methane, dissolved methane will have a concentration that is high enough to achieve the methane equilibrium solubility in water and hydrate system; hence, hydrate can be crystallized within the GHSZ. Since the rate of diffusion of methane is extremely low within the GHSZ, all excess methane relative to the methane equilibrium solubility in water and hydrate system will be precipitated as hydrate in the subsurface. Finally, the hydrate-water system with dissolved methane tends to achieve a thermodynamic equilibrium (Xu and Ruppel 1999; Buffett and Zatsepina 2000). Consequently, the kinetics for hydrate accumulation doesn't have to be taken into account when this thermodynamic equilibrium system of hydrate, water with dissolved methane is considered. By using the thermodynamic equilibrium theory for hydrate-water system, a steady state model can be applied to ODP Site 997 at the Blake Ridge for calculation of hydrate that was distributed from 180 to $450 \mathrm{mbsf}$, and it was found that hydrate occupies no more than 7\% of the sediment pore on average (Davie and Buffett 2001, 2003).

\subsection{Three-Phase Hydrate: Vent Gas Hydrate}

A gas vent is known as a common natural phenomenon distributed widely in marine environments across the world (Kvenvolden and Rogers 2005; Dimitrov 2002; Mazurenko and Soloviev 2003). Free gas migrates from a deep source along conduits toward the seafloor. The vent gas partially precipitates as hydrate within the GSHZ (Chen and Cathles 2003, 2005; Chen et al. 2004a; Cathles and Chen 2004), and partially converts into $\mathrm{CO}_{2}$ to precipitate as seep carbonate in the seafloor and subsurface through microbial process (e.g., Valentine and Reeburgh 2000). Remaining vent gas emerges into the overlying water column to form gas plume in seawater column and is dramatically visible on echo sounder records (e.g., MacDonald et al. 2002; Sassen et al. 2004). Figure 3 shows a concept of this gas vent system in a marine environment.

Gas hydrate was collected on the seafloor at many gas vent sites around the world (MacDonald et al. 2002, 2003; Trehu et al. 2003; Paull et al. 2000; Sassen et al. 2004; Milkov 2000). More recently, free gas was considered to be co-existent with hydrate and water in the shallow sediments at the southern summit of Hydrate Ridge (Milkov et al. 2004) where gas vents and hydrate outcrops on the seafloor (Suess et al. 1999). This evidence suggests that a gas vent site is a co-existent system of hydrate, water and free gas. Thermodynamically, gas could be completely precipitated because the shallow subsurface is within the GHSZ, but gas actively vents out of the seafloor in free gas form. Therefore, we name this type of gas hydrate as a Vent Gas Hydrate. Hence it can be concluded that the hydrate, water and free gas at gas vent site have not reached thermodynamic equilibrium, the hydrate accumulation in the subsurface is kinetically controlled, and the accumulated hydrate within the GHSZ is not stable as a result of the latent heat of hydrate crystallization and the advection of heat by gas flow (Chen and Cathles 2003, 2005; Cathles and Chen 2004; Chen et al. 2004a). 
Based upon the compositional difference of heavier hydrocarbon between source gas and seafloor vent gas, Chen and Cathles (2003) developed a composition-based kinetic model for hydrate crystallization from a vent of thermogenic gas, and applied it to the Bush Hill vent site in the Gulf of Mexico. The result shows that about $10 \%$ of the vent gas crystallizes as hydrate in the subsurface (Cathles and Chen 2004; Chen et al. 2004a). Recently, Cathles et al. (2006) noted that a $30 \mathrm{t} \mathrm{yr}^{-1}$ gas vent $3 \mathrm{~m}$ in diameter with $30 \%$ porosity will plug with hydrate in $\sim 40$ years, suggesting that higher content of gas hydrate can be possibly accumulated in a short time in the subsurface at gas vent site.

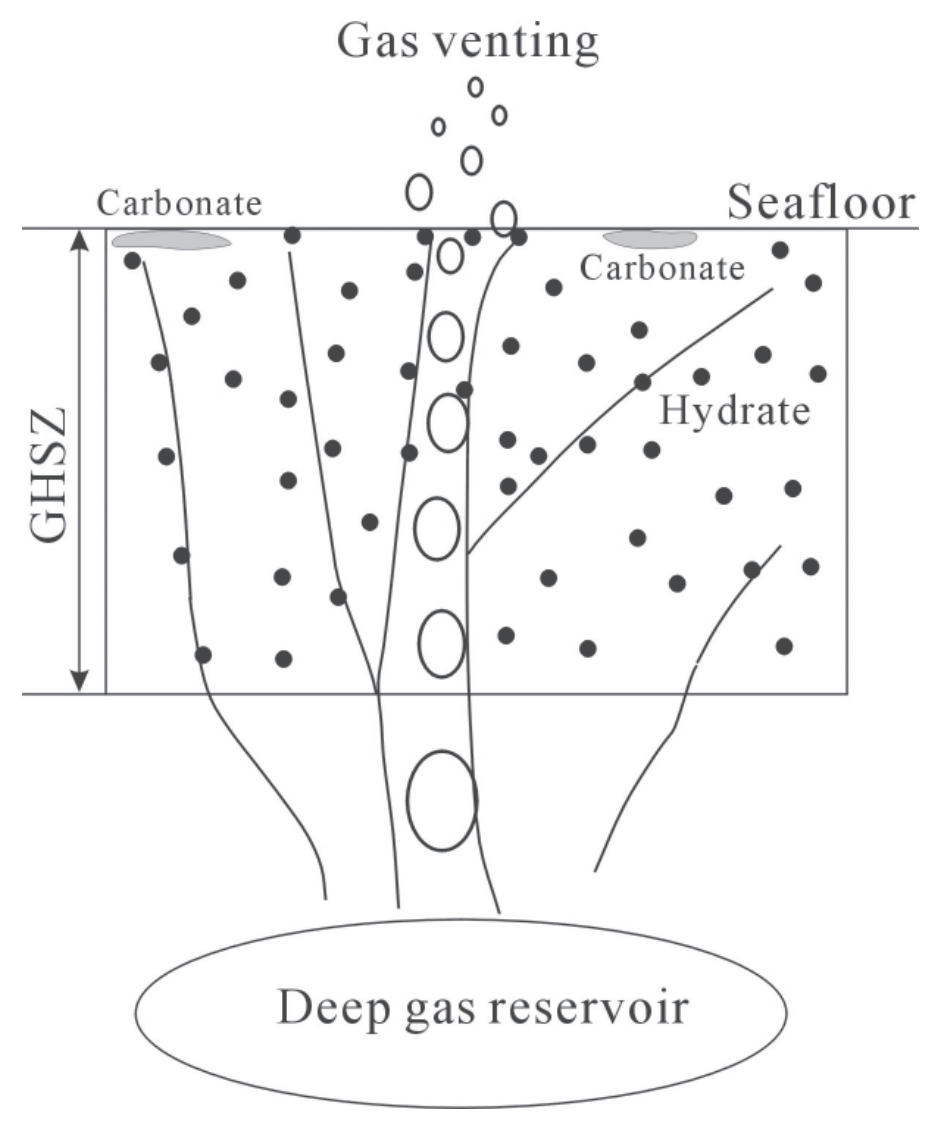

Fig. 3. Conceptual sketch at gas vent site in marine environment. Vent gas partially precipitates as hydrate and partially converts into $\mathrm{CO}_{2}$ to precipitate seep carbonate through microbial process in the subsurface. The remaining gas vents into an overlying seawater column to form a gas plume. It is a three-phase (free gas, hydrate, and water) system occurring within the GHSZ. 


\subsection{Calculation of The Equilibrium Solubility of Methane}

The occurrence of diffusion gas hydrate can be constrained by using the diagram illustrating the relationship between methane solubility and temperature (depth) (Fig. 2b) (Davie and Buffett 2003; Buffett and Zatsepina 2000; Zatsepina and Buffett 1997; Xu and Ruppel 1999). The equilibrium solubility of methane in the hydrate-water system, $X_{2}$ in millimole fraction [mM fraction], can be calculated by using an empirical equation derived from Davies et al. (2004):

$$
X_{2}=X_{3} \exp \left(\frac{T-T_{b}}{\alpha}\right)
$$

Where $X_{3}$ [mM fraction] is the equilibrium solubility of methane in a three-phase system of seawater, hydrate, and free gas at the base of the GHSZ (see equation 4 ). $\alpha$ is $14.5^{\circ} \mathrm{C}$ for seawater (Davie et al. 2004). $T_{b}\left[{ }^{\circ} \mathrm{C}\right]$ is the temperature at the base of the GHSZ, and $T\left[{ }^{\circ} \mathrm{C}\right]$ is the temperature within GHSZ, and can be calculated as:

$$
T=T_{0}+G z
$$

where $T_{0}\left[{ }^{\circ} \mathrm{C}\right]$ is the seafloor temperature, $G\left[{ }^{\circ} \mathrm{C} \mathrm{m}^{-1}\right]$ is the geothermal gradient, and $z[\mathrm{~m}]$ is the depth below the seafloor.

The equilibrium solubility of methane in the three-phase system consisting of hydrate, pure water, and free gas, $X_{3}^{0}$ [mM fraction], can be calculated by using a data-fitting empirical equation developed by Anderson (2004):

$$
X_{3}^{0}=0.0025 \mathrm{~T}^{2}+0.0628 \mathrm{~T}+1.083\left(\mathrm{R}^{2}=0.9999\right) .
$$

The salinity of the pore water will affect the equilibrium solubility of methane in hydratewater-free gas system. By using the method described by Davies et al. (2004), the equilibrium solubility of methane in hydrate-seawater-free gas system with salinity correction is as follows:

$$
X_{3}=X_{3}^{0}(1-\beta S)
$$

where $(1-\beta S)$ is the correction factor for salinity of pore water, $\beta=0.1$ mole $^{-1}$ (Davies et al. 2004), $S$ [mole $1^{-1}$ ] is the pore water salinity.

Figure 4 and Table 1 shows the calculated results of equilibrium solubility of methane by using the measured parameters from Site 1249 of ODP 204 at the southern summit of Hydrate Ridge. The calculated GHSZ is 114 mbsf that is entirely coincident with the depth where the BSR occur (Trehu et al. 2004). The hydrate crystallizing and free gas bobbling on the seafloor requires that dissolved methane in pore water of the seafloor sediment should be larger than $\sim 1.31 \mathrm{mM}$ fraction at the southern summit of Hydrate Ridge (Table 1). The measured con- 
centration of methane in pressure core samples from 13.5 to 14.5 mbsf depth is $~ 67.7-83.2$ $\mathrm{mM}$ fraction (Trehu et al. 2003) that is extremely higher than the equilibrium solubility of methane ( $X_{3}=\sim 1.37 \mathrm{mM}$ fraction) (Table 1), consistent with the fact of that massive hydrate and free gas occurs in the upper most sediments on the seafloor (Suess et al. 1999; Milkov et al. 2004).

\section{HYDRATE OCCURRENCE IN THE NORTHERN SOUTH CHINA SEA}

To explore the gas hydrate potential in the South China Sea, a number of projects have been launched since 1996, and more than $200000 \mathrm{~km}$ seismic reflection profiles have been

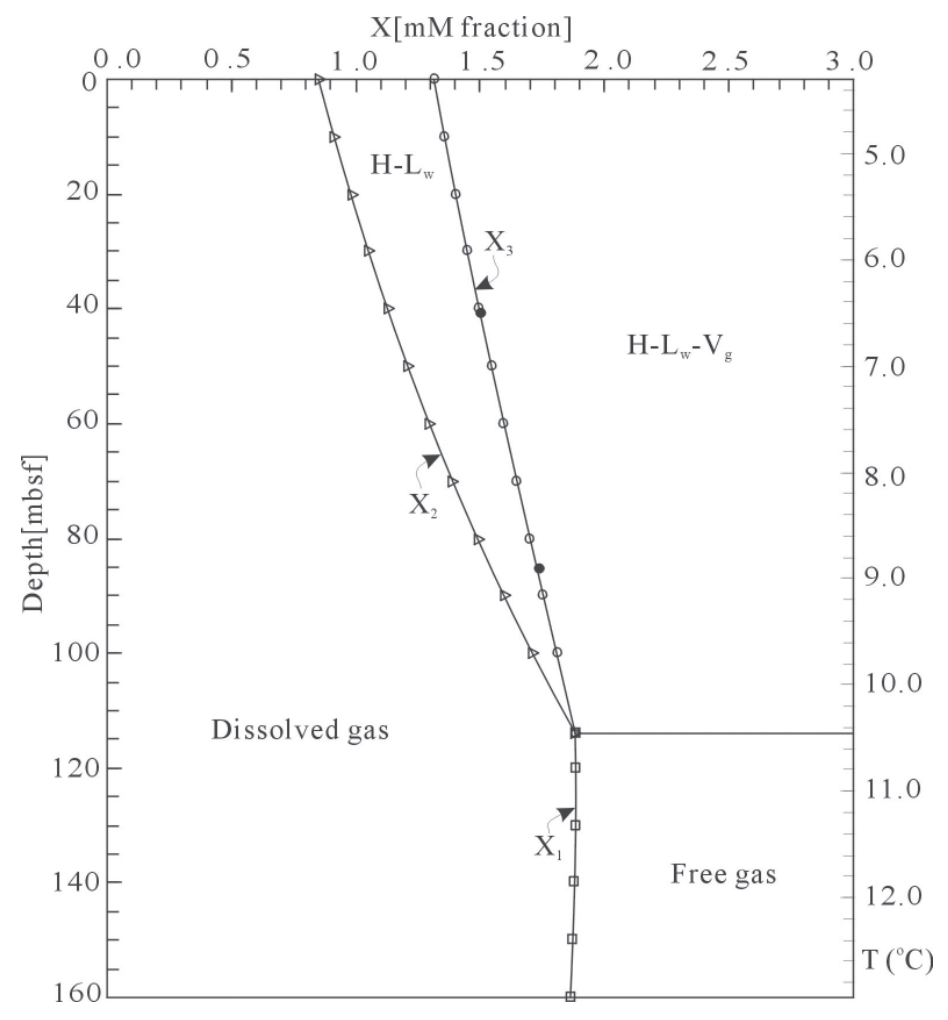

Fig. 4. Equilibrium solubility of methane at site 1249 in the southern summit of Hydrate Ridge. $\mathrm{H}-\mathrm{L}_{\mathrm{w}}$ is hydrate-water system, and $\mathrm{H}-\mathrm{L}_{\mathrm{w}}-\mathrm{V}_{\mathrm{g}}$ is hydrate-water-free gas system. Black dots are measured data from Servio and Englezos (2002) and is consistent with our calculated phase curve of hydrate-gas-seawater system. 
Table 1. The calculated equilibrium solubility of methane at Site 1249 of ODP 204 at the southern summit of Hydrate Ridge.

\begin{tabular}{ccccc}
\hline $\mathrm{z}$ (mbsf) & $\mathrm{T}\left({ }^{\circ} \mathrm{C}\right)$ & $\mathrm{X}_{1}[\mathrm{mM}$ Fraction $] \mathrm{X}_{2}\left[\mathrm{mM}\right.$ Fraction] $\mathrm{X}_{3}[\mathrm{mM}$ Fraction] \\
\hline 0 & 4.31 & 0.86 & 1.31 \\
10 & 4.85 & 0.92 & 1.35 \\
13.5 & 5.04 & & 0.94 & 1.37 \\
14.0 & 5.07 & & 0.95 & 1.37 \\
14.5 & 5.09 & & 0.95 & 1.37 \\
20 & 5.39 & & 0.99 & 1.40 \\
30 & 5.93 & & 1.06 & 1.45 \\
40 & 6.47 & & 1.13 & 1.49 \\
40.6 & 6.50 & & - & $1.50^{*}$ \\
50 & 7.01 & & 1.21 & 1.54 \\
60 & 7.55 & & 1.30 & 1.59 \\
70 & 8.09 & & 1.39 & 1.64 \\
80 & 8.63 & & 1.49 & 1.70 \\
85 & 8.90 & & - & $1.73^{*}$ \\
90 & 9.17 & & 1.60 & 1.75 \\
100 & 9.71 & & 1.71 & 1.81 \\
110 & 10.25 & & 1.84 & 1.86 \\
114 & 10.47 & 1.89 & 1.89 & 1.89 \\
120 & 10.79 & 1.88 & & \\
130 & 11.33 & 1.88 & & \\
140 & 11.87 & 1.87 & & \\
150 & 12.41 & 1.87 & & \\
160 & 12.95 & 1.86 & & \\
\hline
\end{tabular}

Note: $\mathrm{X}_{2}$ and $\mathrm{X}_{3}$ are the equilibrium solubility of methane in hydrate-water system and hydrate-water-free gas system, respectively. $X_{1}$ is the equilibrium solubility of methane in water-free gas system calculated by using the method as described in Duan et al. (1992). The calculated parameters are that the seafloor temperature is $\sim 4.31^{\circ} \mathrm{C}$ at water depth of $\sim 775 \mathrm{~m}$, the average temperature gradient is $\sim 54^{\circ} \mathrm{C} \mathrm{km}^{-1}$, and average salinity is $3.6 \mathrm{wt} \%$ in sediment pore water below $23.41 \mathrm{mbsf}$ (Trehu et al. 2003). The calculated GHSZ is 114 mbsf that is entirely coincident with the depth where the BSR occurs (Trehu et al. 2004). The methane solubility marked with $\operatorname{star}\left(\mathrm{X}^{3}=1.50\right.$ at $6.5^{\circ} \mathrm{C}$, and 1.73 at $\left.8.9^{\circ} \mathrm{C}\right)$ is the measured data in the hydrate-gas-pure water system (Servio and Englezos 2002) with salinity correction (equation 4) by using the $S=0.64$ for $3.6 \mathrm{wt} \%$ salinity. 
collected. BSR was found in reflection seismic records at many locations in the South China Sea (Chow et al. 2000; Chi et al. 1998; Song et al. 2001; Wu et al. 2005; Liu et al. 2006). Mud volcanoes and shale diapirs were reported both on-land and offshore Taiwan (Chi et al. 1998; Chow et al. 2000, 2001; Yang et al. 2004; Chiu et al. 2006) and in the Qiangdongnan Basin (Chen et al. 2004b) in the South China Sea. More recently, some abnormally high methane concentration were found in sea waters and cored sediments (Chen and Tseng 2006; Chuang et al. 2006; Yang et al. 2006). Meanwhile, Chen et al. (2005, 2006a, b) reported seep carbonate in the northeastern South China Sea. Chemosynthetic communities and seep carbonates occurred in an area more than $400 \mathrm{~km}^{2}$ were found on the northern slope of the South China Sea, where water depth is about $500-1000 \mathrm{~m}$ (Zhang et al. 2005). This evidence shows that two types of hydrates possibly occur in the South China Sea. By using parameters from Site 1144 of ODP 184 in the northern South China Sea, the equilibrium solubility of methane in two-phase and three-phase hydrate systems is shown in Fig. 5 and Table 2. The calculated GHSZ is 697 mbsf at Site 1144 where the BSR is possibly located at $654-730 \mathrm{mbsf}$ (Song et al. 2001). Hydrate accumulation and gas bubbling on the seafloor at Site 1144 requires dissolved methane in pore water larger than $\sim 1.23 \mathrm{mM}$ fraction (Table 2).

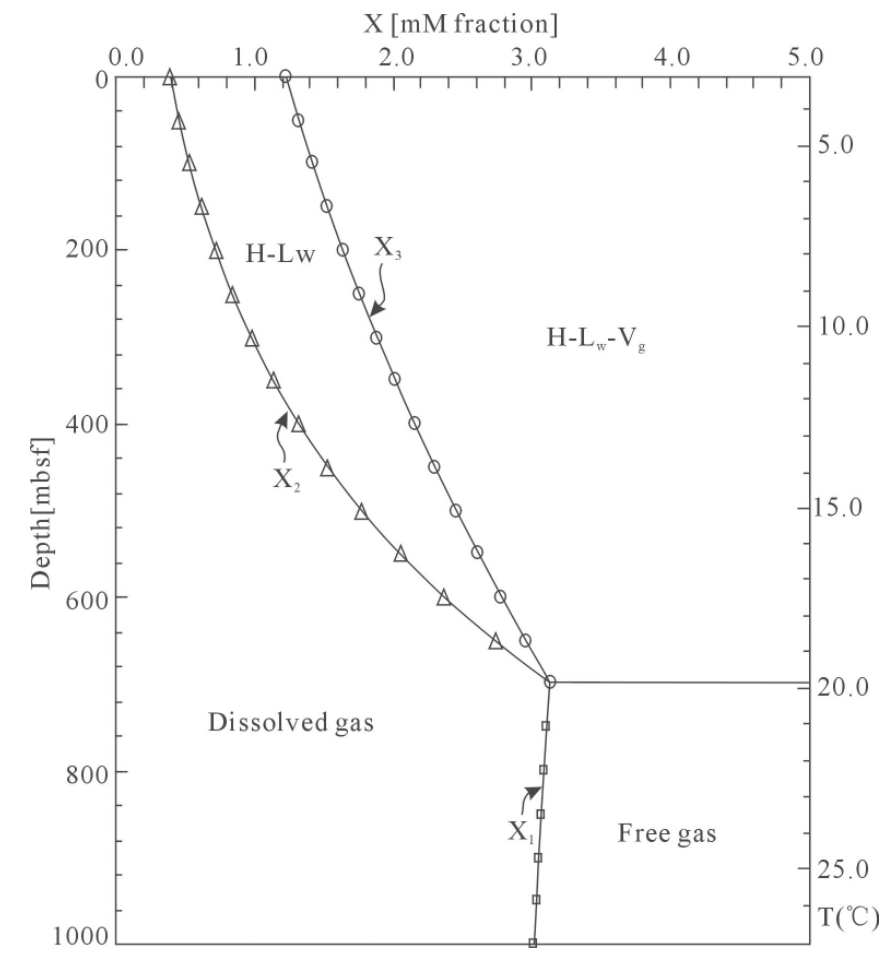

Fig. 5. Equilibrium solubility of methane at site 1144 of ODP 184 in northern South China Sea. 
Table 2. The calculated equilibrium solubility of methane at Site 1144 of ODP 184 in northern South China Sea.

\begin{tabular}{ccccc}
\hline $\mathrm{z}$ (mbsf) & $\mathrm{T}\left({ }^{\circ} \mathrm{C}\right)$ & $\mathrm{X}_{1}\left[\mathrm{mM}\right.$ Fraction] $\mathrm{X}_{2}\left[\mathrm{mM}\right.$ Fraction] $\mathrm{X}_{3}$ [mM Fraction] \\
\hline 0 & 3.1 & & 0.39 & 1.23 \\
50 & 4.3 & & 0.45 & 1.32 \\
100 & 5.5 & & 0.53 & 1.42 \\
150 & 6.7 & & 0.62 & 1.53 \\
200 & 7.9 & & 0.72 & 1.64 \\
250 & 9.1 & & 0.84 & 1.76 \\
300 & 10.3 & & 0.98 & 1.88 \\
350 & 11.5 & & 1.14 & 2.02 \\
400 & 12.7 & & 1.32 & 2.16 \\
450 & 13.9 & & 1.77 & 2.30 \\
500 & 15.1 & & 2.05 & 2.46 \\
550 & 16.3 & & 2.37 & 2.62 \\
600 & 17.5 & & 2.74 & 2.78 \\
650 & 18.7 & 3.13 & 3.13 \\
697 & 19.8 & 3.13 & & \\
750 & 21.1 & 3.10 & & \\
800 & 22.3 & 3.08 & & \\
850 & 23.5 & 3.07 & & \\
900 & 24.7 & 3.05 & & \\
950 & 25.9 & 3.03 & & \\
1000 & 27.1 & 3.02 & & \\
\hline
\end{tabular}

Note: The calculated parameters are that the seafloor temperature is $\sim 3.1^{\circ} \mathrm{C}$ at water depth of $2037 \mathrm{~m}$, and the temperature gradient is $\sim 24^{\circ} \mathrm{C} \mathrm{km}^{-1}$ in the uppermost $150 \mathrm{mbsf}$. No salinity data are available for site 1144, hence we use an average of $3.16 \mathrm{wt} \%$ in sediment pore water at site 1146 (Prell et al. 2003) as the salinity in our calculation. The calculated GHSZ is 697 mbsf at Site 1144 that is consistent with the depth where the BSR is located at $654-730$ mbsf (Song et al. 2001).

\section{CONCLUSIONS}

Gas hydrates in a marine environment can be grouped into two categories, the diffusion gas hydrate and the vent gas hydrate. These two types of gas hydrate show distinction in occurrence, gas source, manner of gas migration, and thermodynamics of system. The gas 
source for diffusion gas hydrate is mainly in situ biogenic methane. Methane dissolves in pore water, no free gas exists within the GHSZ, and the hydrate system is a thermodynamically equilibrium system of water and hydrate (two-phase). Hydrate accumulation is thermodynamically controlled and hydrate occurs in a distance apart from the seafloor and generally in low concentration. Vent gas hydrate occurs at a gas vent site and is a thermodynamically disequilibrium system of water, hydrate, and free gas (three-phase). Gas consists mainly of thermogenic gas originating from deep oil and gas reservoirs and hydrate is imbedded in shallow sediments with high content. Hydrate accumulation is kinetically controlled. Available data reported to date show that both the diffusion gas hydrate and the vent gas hydrates possibly occur in the South China Sea.

Acknowledgements This study was partially supported by the Chinese Academy of Sciences (Project No: KZCX3-SW-224 and GIGCX-04-03) and the NSFC (Grant No: 40572071). We are grateful to the gust editors, Professors Ju-Chin Chen, Char-Shine Liu, Chi-Yue Huang and Tsanyao Frank Yang, and anonymous reviewers for comments that greatly improved the manuscript.

\section{REFERENCES}

Anderson, G. K., 2004: Enthalpy of dissociation and hydration number of methane hydrate from the Clapeyron equation. J. Chem. Thermodyn., 36, 1119-1127.

Buffett, B. A., and O. Y. Zatsepina, 2000: Formation of gas hydrate from dissolved gas in nature porous media. Mar. Geol., 164, 69-77.

Cathles, L. M., and D. F. Chen, 2004: A compositional kinetic model of hydrate crystallization and dissolution. J. Geophys. Res., 109, doi:10.1029/2003JB002910.

Cathles, L. M., D. F. Chen, and B. F. Nicholson, 2006: A dimensionless vent number characterizing the thermal impact of fluid discharge through planar and cylindrical vents with particular application to seafloor gas vents crystallizing hydrate. J. Geophys. Res., 111, B10205, doi:10.1029/2005JB004221.

Chen, C. T. A., and H. C. Tseng, 2006: Abnormally high $\mathrm{CH}_{4}$ concentrations in seawater at mid-depths on the continental slopes of the northern South China Sea. Terr. Atmos. Ocean. Sci., 17, 951-959.

Chen, D. F., and L. M. Cathles, 2003: A kinetic model for the pattern and amounts of hydrate precipitated from a gas steam: application to the Bush Hill vent site, Green Canyon Block 185, Gulf of Mexico. J. Geophys. Res., 108, 2058, doi:10.1029/2001JB001597.

Chen, D. F., L. M. Cathles, and H. H. Roberts, 2004a: The chemical signatures of variable gas venting at hydrate sites. Mar. Petrol. Geol., 21, 317-326.

Chen, D. F., X. X. Li, and B. Xia, 2004b: Distribution of gas hydrate stable zone and resource prediction in Qiongdongnan Basin in South China Sea. Chin. J. Geophys., 47, 483-489. (in Chinese)

Chen, D. F., and L. M. Cathles, 2005: On the thermal impact of gas venting and hydrate crystallization, J. Geophys. Res., 110, B11204, doi:10.1029/2004JB003533. 
Chen, D. F., Y. Y. Huang, X. L. Yuan., and L. M. Cathles, 2005: Seep carbonates and their preserved methane oxidizing archaea and reducing bacteria fossils near Dongsha Island in South China Sea. Mar. Petrol. Geol., 22, 613-621.

Chen, D. F., D. Feng, Z. Su, Z. G. Song, G. Q. Chen, and L. M. Cathles, 2006a: Pyrite crystallization in seep carbonates at gas vent and hydrate site, Mat. Sci. Eng. C, 26, 602-605.

Chen, Z., W. Yan, M. H. Chen, S. H. Wang, J. Lu, F. Zhang, R. Xiang, S. B. Xiao, P. Yan, and S. C. Gu, 2006b: Discovery of seep carbonate nodules as new evidence for gas venting on the northern continental slope of South China Sea. Chin. Sci. Bull., 51, 1228-1237.

Chi, W. C., D. L. Reed, C. S. Liu, and N. Lundberg, 1998: Distribution of the bottom-simulating reflector in the offshore Taiwan collision zone. Terr. Atmos. Ocean. Sci., 9, 779794.

Chiu, J. K., W. H. Tseng, and C. S. Liu, 2006: Distribution of gassy sediments and mud volcanoes offshore southwestern Taiwan. Terr. Atmos. Ocean. Sci., 17, 703-722.

Chow, J., J. S. Lee, R. Sun, C. S. Liu, and N. Lundberg, 2000: Characteristics of the bottom simulating reflectors near mud diapirs: offshore southwestern Taiwan. Geo-Mar. Lett., 20, 3-9.

Chow, J., J. S. Lee, C. S. Liu, B. D. Lee, and J. S. Watkins, 2001: A submarine canyon as the cause of a mud volcano - Liuchieuyu Island in Taiwan. Mar. Geol., 176, 55-63.

Chuang, P. C., T. F. Yang, S. Lin, H. F. Lee, T. F. Lan, W. L. Hong, C. S. Liu, J. C. Chen, and Y. Wang, 2006: Extremely high methane concentration in bottom water and cored sediments from offshore southwestern Taiwan. Terr. Atmos. Ocean. Sci., 17, 903-920.

Davie, M. K., and B. A. Buffett, 2001: A numerical model for the formation of gas hydrate below the seafloor. J. Geophys. Res., 106, 497-514.

Davie, M. K., and B. A. Buffett, 2003: A steady state model for marine hydrate formation: constraints on methane supply from pore water sulfate profiles. J. Geophys. Res., 108, 2495, doi:10.1029/2002JB002300.

Davie, M. K., O. Y. Zatsepina, and B. A. Buffett, 2004: Methane solubility in marine hydrate environments. Mar. Geol., 203, 177-184.

Dimitrov, L. I., 2002: Mud volcanoes- the most important pathway for degassing deeply buried sediments. Earth-Sci. Rev., 59, 49-76.

Duan, Z., N. Moller, J. Greenberg, and J. H. Weare, 1992: The prediction of methane solubility in natural waters to high ionic strength from 0 to $250^{\circ} \mathrm{C}$ and from 0 to $1600 \mathrm{bar}$. Geochim. Cosmochim. Acta, 56, 1451-1460.

Heeschen, K. U., 2003: Distribution and height of methane bubble plumes on the Cascadia Margin characterized by acoustic imaging, Geophys. Res. Lett., 30, 1643, doi:10.1029/ 2003 GL016974.

Hyndman, R. D., and E. E. Davis, 1992: A mechanism for the formation of methane hydrate and seafloor bottom-simulating reflectors by vertical fluid expulsion. J. Geophys. Res., 97, 7025-7041.

Kvenvolden, K. A., and T. D. Lorenson, 2001: The global occurrence of natural gas hydrates. In: Paull, C. K., and W. P. Dillon (Eds.), Natural Gas Hydrates: Occurrence, Distribution, and Detection, AGU, Washing, D. C., 3-18.

Kvenvolden, K. A., and B. W. Rogers, 2005: Gaia's breath-global methane exhalations. Mar. Petrol. Geol., 22, 579-590. 
Leifer, I., and I. R. MacDonald, 2003: Dynamics of the gas flux from shallow gas hydrate deposits: interaction between oily hydrate bubbles and the oceanic environment. Earth Planet. Sci. Lett., 21, 411-421.

Liu, C. S., P. Schnürle, Y. Wang, S. H. Chung, S. C. Chen, and T. H. Hsiuan, 2006: Distribution and characters of gas hydrate offshore of southwestern Taiwan. Terr. Atmos. Ocean. Sci., 17, 615-644.

MacDonald, I. R., I. Leifer, R. Sassen, P. Stine, R. Mitchell, and N. L. Guinasso Jr, 2002: Transfer of hydrocarbons from natural seeps to the water column and atmosphere. Geofluids, 2, 95-107.

MacDonald, I. R., W. W. Sager, and M. B. Peccin, 2003: Gas hydrate and chemosynthetic biota in mounded bathymetry at mid-slope hydrocarbon seeps: Northern Gulf of Mexico. Mar. Geol., 198, 133-158.

Mazurenko, L. L., and V. A. Soloviev, 2003: Worldwide distribution of deep-water fluid venting and potential occurrences of gas hydrate accumulations. Geo-Mar. Lett., 23, 162-176.

Milkov, A. V., 2000: Worldwide distribution of submarine mud volcanoes and associated gas hydrates. Mar. Geol., 167, 29-42.

Milkov, A. V., G. R. Dickens, G. E. Claypool, Y. J. Lee, W. S. Borowski, M. E. Torres, W. Y. Xu, H. Tomaru, A. M. Trehu, and P. Schultheiss, 2004: Co-existence of gas hydrate, free gas, and brine within the regional gas hydrate stability zone at Hydrate Ridge (Oregon margin): evidence from prolonged degassing of a pressurized core. Earth Planet. Sci. Lett., 222, 829-843.

Paull, C. K., R. Matsumoto, P. J. Wallace, and W. P. Dillon, 2000: Proc. ODP, Init. Repts. 164 [Online]. http://www-odp.tamu.edu/publications/164 SR/.

Prell, W. L., P. Wang, P. Blum, D. K. Rea, and S. C. Clemens, 2003: Proc. ODP, Sci. Results, 184 [Online]. http://www-odp.tamu.edu/publications/184 SR/.

Sassen, R., S. L. Losh, L. M. Cathles III, H. H. Roberts, J. K.Whelan, A. V. Milkov, S. T. Sweet, and D. A. DeFreitas, 2001: Massive vein-filling gas hydrate: relation to ongoing gas migration from the deep subsurface in the Gulf of Mexico. Mar. Petrol. Geol., 18, 551-560.

Sassen, R., H. H. Roberts, R. Carney, A. V. Milkov, D. A. DeFreitas, B. Lanoil, and C. Zhang, 2004: Free hydrocarbon gas, gas hydrate, and authigenic minerals in chemosynthetic communities of the northern Gulf of Mexico continental slope: relation to microbial processes. Chem. Geol., 205, 195-217.

Servio, P., and P. Englezos, 2002: Measurement of dissolved methane in water in equilibrium with its hydrate. J. Chem. Eng. Data, 47, 87-90.

Song, H. B., J. H. Geng, H. K. Wang, W. S. Zhang, Y. X. Fang, T. Y. Hao, and W. W. Jian, 2001: A preliminary study of gas hydrates in Dongsha region north of South China Sea. Chin. J. Geophys., 44, 687-695. (in Chinese)

Sloan, E. D., 1998: Clathrate hydrates of natural gases, $2^{\text {nd }}$ Ed., Marcel Dekker, New York, $628 \mathrm{pp}$.

Suess, E., M. E. Torres, G. Bohrmann, R. W. Collier, J. Greinert, P. Linke, G. Rehder, A. Trehu, K. Wallmann, G. Winckler, and E. Zuleger, 1999: Gas hydrate destabilization: 
enhanced dewatering, benthic material turnover and large methane plumes at the Cascadia convergent margin. Earth Planet. Sci. Lett., 170, 1-15.

Trehu, A. M., G. Bohrmann, F. R. Rack, M. E. Torres, and Shipboard Scientific Party, 2003: Proc. ODP, Init. Repts. 204 [Online]. http://www-odp.tamu.edu/publications/204 IR/.

Trehu, A. M., P. E. Long, M. E. Torres, G. Bohrmann, F. R. Rack, T. S. Collett, D. S. Goldberg, A. V. Milkov, M. Riedel, P. Schultheiss, N. L. Bangs, S. R. Barr, W. S. Borowski, G. E. Claypool, M. E. Delwiche, G. R. Dickens, E. Gracia, G. Guerin, M. Holland, J. E. Johnson, Y. J. Lee, C. S. Liu, X. Su, B. Teichert, H. Tomaru, M. Vanneste, M. Watanabe, and J. L. Weinberger, 2004: Three-dimensional distribution of gas hydrate beneath southern Hydrate Ridge: constraints from ODP Leg 204. Earth Planet. Sci. Lett., 222, 845-862.

Valentine, D. L., and W. S. Reeburgh, 2000: New perspectives on anaerobic methane oxidation. Environ. Microbiol., 2, 477-484.

Wu, S. G., G. Zhang, Y. Huang, J. Liang, and H. K. Wong, 2005: Gas hydrate occurrence on the continental slope of the northern South China Sea. Mar. Petrol. Geol., 22, 403-412.

Xu, W., and C. Ruppel, 1999: Predicting the occurrence, distribution, and evolution of methane gas hydrate in porous marine sediments. J. Geophys. Res., 104, 5081-5095.

Yang, T. F., G. H. Yeh, C. C. Fu, C. C. Wang, T. F. Lan, H. F. Lee, C. H. Chen, V. Walia, and Q. C. Sung, 2004: Composition and exhalation flux of gases from mud volcanoes in Taiwan. Environ. Geol., 46, 1003-1011.

Yang, T. F., P. C. Chuang, S. Lin, J. C. Chen, Y. Wang, and S. H. Chung, 2006: Methane venting in gas hydrate potential area offshore of SW Taiwan: evidence of gas analysis of water column samples. Terr. Atmos. Ocean. Sci., 17, 933-950.

Zatsepina, O. Y., and B. A. Buffett, 1997: Phase equilibrium of gas hydrate: implications for the formation of hydrate in the deep sea floor. Geophys. Res. Lett., 24, 1567-1570.

Zhang, H. Q., L. S. Wu, and J. W. Zhang, 2005: Application of the seafloor visualization technique in gas hydrate exploration. Geol. Bull. China, 24, 185-188. (in Chinese)

Chen, D. F., Z. Su, and L. M. Cathles, 2006: Types of gas hydrates in marine environments and their thermodynamic characteristics. Terr. Atmos. Ocean. Sci., 17, 723-737. 